\title{
Washed Red Blood Cells
}

National Cancer Institute

\section{Source}

National Cancer Institute. Washed Red Blood Cells. NCI Thesaurus. Code C133357.

Red blood cells typically washed using normal saline with or without small amounts of dextrose using manual or automated methods. The washed red blood cells are stored at 1-6 degrees $C$ for up to 24 hours. 